2

I N S A N

\title{
INSAN
}

Jurnal Psikologi dan Kesehatan Mental

http://e-journal.unair.ac.id/index.php/JPKM

p-ISSN 2528-0104 | e-ISSN 2528-5181

ARTIKEL PENELITIAN

\section{Pengaruh Fundamentalisme Agama terhadap Narsisme Kolektif dan Out- Group Derogation pada Aktivitas Mahasiswa Perguruan Tinggi Negeri}

\author{
DIAH BUDIARTI \& RAHKMAN ARDI* \\ Departemen Psikologi Kepribadian dan Sosial, Fakultas Psikologi Universitas Airlangga
}

\begin{abstract}
ABSTRAK
Penelitian ini berfokus pada temuan pelanggaran kebebasan beragama/berkeyakinan (KBB) di lingkungan perguruan tinggi negeri (PTN), antara lain sumpah atas tegaknya khilafah, persetujuan terhadap syariah sebagai pedoman bernegara, serta lingkungan kampus yang cenderung dikuasai kelompok fundamentalis karena mahasiswa memiliki paham keagamaan yang kaku dan kerap salah paham. Langkah kebijakan institusi pendidikan terkait temuan tersebut hanya bersifat klarifikasi dan belum mencakup penelusuran terhadap akar permasalahan pelanggaran KBB. Hipotesis penelitian adalah fundamentalisme agama merupakan faktor yang berpengaruh terhadap kecenderungan bias (narsisme kolektif dan out-group derogation) pada aktivis mahasiswa PTN. Metode penelitian berupa eksperimen dengan pemberian priming yang pada penelitian sebelumnya terbukti meningkatkan kecenderungan bias. Subjek penelitian adalah 203 (N=203) mahasiswa PTN yang tergabung dalam organisasi mahasiswa ekstra kampus berbasis Islam. Hasil penelitian menunjukkan fundamentalisme agama tidak berpengaruh signifikan terhadap narsisme kolektif dan out-group derogation. Pemberian priming tidak terbukti meningkatkan kecenderungan bias (narsisme kolektif dan out-group derogation) pada aktivis mahasiswa PTN.
\end{abstract}

Kata kunci: fundamentalisme agama, narsisme kolektif, out-group derogation, priming

\section{ABSTRACT}

This study focuses on the findings of violations in freedom of religion/belief (KBB) in state universities (PTN), i.e. oaths on the establishment of khilafah, approval of sharia as a state guidelines, and campus environment tend to be dominated by fundamentalists as students hold rigid religious belief. Educational institutions policy related to these findings are limited to clarification and has not included any cause of KBB violations. Research hypothesis is that religious fundamentalism is a factor that influences collective narcissism and out-group derogation in PTN student activists. An experiment using priming, which in previous study has been shown to increase bias tendency is used. Subjects are 203 $(\mathrm{N}=203)$ PTN students who join Islamic campus-based extra student organizations. Results show that religious fundamentalism has no significant effect on collective narcissism and out-group derogation. Priming is not proven to increase the bias tendency (collective narcissism and out-group derogation) in PTN students.

Keywords: collective narcissism, out-group derogation, priming, religious fundamentalism 
INSAN Jurnal Psikologi dan Kesehatan Mental, 2019, Vol. 4(2), 54-63, doi: 10.20473/jpkm.v4i22019.54-63 Dikirimkan: 16 Oktober 2019 Diterima: 10 Desember 2019 Diterbitkan: 27 Februari 2020

Editor: Rizqy Amelia Zein

*Alamat korespondensi: Fakultas Psikologi Universitas Airlangga, Jalan Airlangga 4-6 Surabaya 60286. Posel: rahkman.ardi@psikologi.unair.ac.id

Naskah ini merupakan naskah dengan akses terbuka dibawah ketentuan the Creative Common Attribution License (http://creativecommons.org/licenses/by/4.0), sehingga penggunaan, distribusi, reproduksi dalam media apapun atas artikel ini tidak dibatasi, selama sumber aslinya disitir dengan baik.

\section{P E N D A H U L U A N}

Aktivitas kelompok berkaitan dengan intoleransi agama muncul sebagai ancaman memecah belah Indonesia. Hal ini tercermin dari penelitian Setara Institute yang memuat 151 kasus pelanggaran kebebasan beragama/berkeyakinan (KBB) sepanjang 2017. Sebanyak 126 kasus pelanggaran KBB dilakukan oleh individu dan organisasi masyarakat antara lain Aliansi Ormas Islam, MUI dan FPI (Nadhlir, 2018). Diskusi Sekolah Pengelolaan Keragaman (SPK) dan Program Studi Lintas Agama dan Budaya (CRCS) UGM tahun 2016 menyebutkan bentuk-bentuk intoleransi yang dilakukan kelompok agama antara lain kekerasaan terhadap Ahmadiyah dan Syiah, penutupan gereja, kampanye anti perbedaan, peraturan daerah yang diskriminatif, serta pelanggaran hak-hak sipil (Dhani, 2016).

Pelanggaran KBB juga dilakukan aktivis mahasiswa yang belajar di perguruan tinggi negeri. Salah satu gerakan yang cukup besar adalah sumpah mahasiswa untuk tegaknya khilafah yang dilakukan di Kampus IPB Dramaga Bogor melalui koordinasi Badan Koordinasi Lembaga Dakwah Kampus (BKLDK). Kegiatan tersebut diikuti oleh 1.500 mahasiswa yang menggelar simposium pada 25-27 Maret 2016 (Heriyanto, 2018). Data yang dihimpun Gerakan Mahasiswa dan Pemuda Indonesia (GMPI) tahun 2006 menyebutkan bahwa hanya 4,5\% mahasiswa sepakat Pancasila sesuai dengan ideologi bangsa, 80\% lainnya lebih menyetujui syariah sebagai pedoman bernegara, serta 15,5\% memilih sosialisme. Responden penelitian ini merupakan mahasiswa 11 kampus besar di Indonesia yaitu UI, UGM, ITB, IPB, Unair, Unibraw, Unpad, Unhas, Unand, Unsri, dan Unsyiah (Sahlan, 2017).

Fenomena-fenomena pelanggaran KBB merupakan gambaran kecenderungan konsep diri berdasarkan keanggotaan kelompok. Dalam Psikologi Sosial, fenomena tersebut dijelaskan oleh teori identitas sosial. Psikolog sosial Henry Tajfel mengamati fenomena kecenderungan orang-orang untuk melihat kelompoknya lebih baik daripada kelompok lain (bias kelompok). Menurut Tajfel, hasrat untuk memandang diri secara positif kemudian diwujudkan pada kelompok sehingga membentuk tendensi untuk melihat diri sendiri secara positif kemudian diwujudkan pada level kelompok sehingga membentuk tendensi melihat in-group dibanjiri dengan nilai-nilai positif. Sebaliknya, out-group adalah kelompok yang penuh dengan nilai-nilai negatif (Tajfel, 2010).

Pada studinya berjudul Group Psychology and the Analysis of the Ego, Sigmund Freud mencatat bagaimana setiap penghuni wilayah kecil melihat penghuni wilayah lain dengan rasa jijik. Temuan ini kemudian menjadi asal istilah Freud's theory of collective narcissism (Freud \& Dickson, 1985). Konsep collective narcissism (selanjutnya disebut narsisme kolektif) disoroti kembali oleh de Zavala dkk (2009) yang menciptakan skala narsisme kolektif dan mengembangkan penelitian intergroup and political consequences of collective narcissism.

Narsisme kolektif dimaknai sebagai kecenderungan individu membesar-besarkan citra positif dan nilai penting kelompok (in-group). Individu-individu dengan skor narsisme kolektif yang tinggi menyetujui

INSAN Jurnal Psikologi dan Kesehatan Mental

Tahun 2019, Vol. 4(2), 54-63

doi: $10.20473 /$ jpkm.v4i22019.54-63

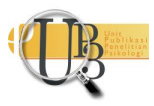


bahwa nilai hakiki dari kelompoknya tidak cukup diakui oleh kelompok lain dan bahwa kelompoknya layak mendapatkan perlakuan khusus. Mereka bersikeras agar kelompoknya mendapatkan perlakuan dan penghormatan khusus (de Zavala dkk, 2009). Narsisme kolektif dapat dimiliki seorang individu terkait kelompok sosial apapun. Partisipan dalam studi de Zavala dkk (2009) menyetujui pernyataanpernyataan dalam skala narsisme kolektif terkait kelompok: nasional, etnis, agama, ideologis, politis, kemahasiswaan, penggemar sepak bola, kelompok profesional dan organisasi (de Zavala dkk, 2009).

Narsisme kolektif juga berkaitan dengan out-group derogation, yakni sikap negatif pada out-group yang dianggap mengancam anggota in-group (de Zavala dkk, 2013). Schiefer dkk (2010) mengungkapkan bahwa semakin tinggi hierarki kultural individu, maka semakin tinggi tendensi menampilkan sikap negatif terhadap out-group. Efek yang terjadi lebih tinggi pada remaja dengan usia yang lebih dewasa dibandingkan pada anak-anak.

Johnson, dkk. (2012) mengungkapkan bahwa penelitian mengenai bias antarkelompok agama lebih tepat dilakukan dengan mengacu pada identitas yang terbentuk atas nilai-nilai religius. Dalam kaitannya dengan religiusitas, penelitian sebelumnya menemukan adanya hubungan antara identitas berdasarkan nilai-nilai religius dengan bias antarkelompok (Johnson dkk, 2012).

Altemeyer dan Hunsberger (1992) mengungkapkan individu dengan tipe kepribadian right-wing authoritarianism (RWA) cenderung lebih berprasangka. Hal ini disebabkan karakteristik RWA antara lain kecenderungan berperilaku religius dalam banyak cara. Studi yang dilakukan di Amerika Utara menunjukkan secara konsisten bahwa RWA cenderung membawa ajaran agama saat kecil sampai dewasa, lebih sering pergi ke gereja dan membaca kitab suci lebih sering daripada tipe kepribadian yang lain. Mereka juga sangat jarang meragukan agamanya selama hidup (Altemeyer \& Hunsberger, 1992). Namun, studi lain yang dilakukan Altemeyer dan Hunsberger (1992) juga menemukan bahwa individu dengan tipe kepribadian RWA memiliki korelasi negatif dengan prasangka. Hal ini terjadi karena alat ukur yang digunakan untuk mengukur prasangka hanya berfokus pada konten-konten kepercayaan religius.

Altemeyer dan Hunsberger (1992) menemukan kosep religious fundamentalism (selanjutnya disebut fundamentalisme agama) berkorelasi positif dengan RWA dan perilaku-perilaku prasangka. Fundamentalisme agama didefinisikan sebagai kepercayaan terhadap seperangkat ajaran agama yang secara jelas mengandung kebenaran fundamental, dasar, esensial, dan tidak dapat diganggu gugat tentang kemanusiaan dan ketuhanan. Individu yang memiliki tingkat fundamentalisme agama yang tinggi beranggapan bahwa kebenaran esensial ini pada dasarnya ditentang oleh kekuatan jahat yang harus dilawan dengan penuh semangat; bahwa kebenaran ini harus dilestarikan sesuai praktik-praktik mendasar dan tidak dapat diubah; dan bahwa mereka yang percaya dan mengikuti ajaran mendasar ini memiliki hubungan khusus dengan Tuhan (Altemeyer \& Hunsberger, 1992). Karakteristik fundamentalisme agama antara lain adanya penerjemahan secara literal terhadap kitab suci, dogma, atau ideologi, serta perasaan yang kuat akan pentingnya mempertahankan perbedaan in-group dan outgroup (Altemeyer \& Hunsberger, 1992).

Kepercayaan fundamentalisme dikaitkan dengan sumber-sumber agresi dan ketakutan terhadap dunia yang berbahaya, serta pembenaran diri. Melalui dua kali studi replikasi juga ditemukan bahwa otoritarian mengurangi rasa bersalah mereka hampir sepenuhnya melalui agama (Altemeyer \& Hunsberger, 1992). Kepribadian otoritarian sayap kanan berkorelasi positif dengan prasangka terhadap kelompok yang diharamkan dalam agama seseorang (Duck \& Hunsberger, 1999). Studi yang dilakukan dengan sebagian besar sampel mahasiswa Kristen di AS Selatan hingga Tengah menemukan fundamentalisme agama sebagai prediktor paling kuat dari sikap negatif tersirat terhadap kelompok homoseksual yang merupakan kelompok minoritas (Rowatt dkk, 2006). Melalui metode priming, terdapat peningkatan bias yang signifikan ketika representasi kognitif atas agama diaktifkan (Johnson INSAN Jurnal Psikologi dan Kesehatan Mental Tahun 2019, Vol. 4(2), 54-63 doi: $10.20473 /$ jpkm.v4i22019.54-63 
dkk, 2012). Fundamentalisme agama memiliki korelasi negatif dengan sikap positif terhadap kelompok yang dianggap melanggar pandangan agama (Johnson dkk, 2012).

Dalam penelitian ini, fundamentalisme agama dipilih sebagai faktor yang memengaruhi narsisme kolektif dan out-group derogation pada aktivis mahasiswa perguruan tinggi negeri. Fundamentalisme agama dipilih berdasarkan karakteristik adanya perasaan yang kuat akan pentingnya mempertahankan perbedaan in-group dan out-group, pembenaran diri, serta sumber-sumber agresi terhadap out-group (Altemeyer \& Hunsberger, 1992).

Fokus penelitian ini adalah pelanggaran KBB yang dilakukan di lingkungan perguruan tinggi negeri. Langkah kebijakan institusi pendidikan terkait temuan-temuan tersebut hanya berupa klarifikasi dan belum mencakup penelusuran terhadap akar permasalahan yang sebenarnya (Heriyanto, 2018). Penelitian ini bertujuan untuk menguji secara empiris pengaruh fundamentalisme agama terhadap narsisme kolektif dan out-group derogation yang dimoderasi priming pada aktivis mahasiswa perguruan tinggi negeri. Penelitian ini bermanfaat sebagai validasi teori-teori bias kelompok sebelumnya dan dapat digunakan dalam usaha penelusuran penyebab kasus-kasus prasangka antaragama di lingkungan kampus.

Hipotesis dalam penelitian ini adalah:

$\mathrm{Ho}_{1}$ : Fundamentalisme agama tidak berpengaruh signifikan terhadap narsisme kolektif.

$\mathrm{Ha}_{1}$ : Fundamentalisme agama berpengaruh signifikan terhadap narsisme kolektif.

$\mathrm{Ho}_{2}$ : Fundamentalisme agama tidak berpengaruh signifikan terhadap out-group derogation.

$\mathrm{Ha}_{2}$ : Fundamentalisme agama berpengaruh signifikan terhadap out-group derogation.

$\mathrm{H}_{3}$ : Fundamentalisme agama berpengaruh pengaruh positif terhadap narsisme kolektif ketika subjek diekspos dengan priming.

$\mathrm{H}_{4}$ : Fundamentalisme agama berpengaruh pengaruh positif terhadap out-group derogation ketika subjek diekspos dengan priming.

\section{E T O D E}

\section{Partisipan}

Subjek penelitian ini adalah mahasiswa PTN yang tergabung dalam organisasi mahasiswa ekstra kampus berbasis Islami.

\section{Prosedur}

Variabel dalam penelitian ini adalah narsisme kolektif $\left(\mathrm{Y}_{1}\right)$, out-group derogation $\left(\mathrm{Y}_{2}\right)$, fundamentalisme agama (X) dan priming (Z). Penelitian ini merupakan penelitian kuantitatif dengan eksperimen berupa pemberian priming. Desain eksperimen two independent groups digunakan dalam penelitian ini. Jumlah sampel minimum dalam penelitian ini sejumlah 51 subjek untuk masing-masing kelompok kontrol dan eksperimen. Jumlah ini dihitung menggunakan modul jpower (The Jamovi Project, 2019) dengan kondisi besaran efek yang diharapkan minimal 0,5; besaran power 0,$8 ; \alpha=0,05$; uji statistik one-tailed.

Prosedur eksperimen dalam penelitian ini adalah sebagai berikut:

1. Randomisasi dilakukan dengan lemparan koin guna menentukan pengisian kuesioner yang berisi dua kondisi yang berbeda untuk masing-masing subjek.

2. Pada kelompok kontrol, subjek mengisi kuesioner dengan urutan: kuesioner demografi $\rightarrow$ kuesioner fundamentalisme agama $\rightarrow$ kuesioner narsisme kolektif $\rightarrow$ termometer perasaan. 
3. Pada kelompok eksperimen, subjek mengisi kuesioner dengan urutan: kuesioner demografi $\rightarrow$ kuesioner fundamentalisme agama $\rightarrow$ kuesioner kuesioner priming $\rightarrow$ kuesioner narsisme kolektif $\rightarrow$ termometer perasaan.

\section{Pengukuran}

Instrumen penelitian berupa kuesioner demografis, kuesioner fundamentalisme agama oleh Altemeyer dan Hunsberger (1992) dan kuesioner narsisme kolektif oleh de Zavala dkk (2013) dengan penyesuaian referensi in-group sebagai kelompok muslim. Priming dalam penelitian ini dilakukan dengan memberikan stimulus berupa tugas yang melibatkan kata-kata representatif agama Islam seusai dengan temuan Johnson dkk (2012). Out-group derogation diukur menggunakan termometer perasaan oleh Alwin (1997, dalam de Zavala dkk, 2013) dengan penyesuaian out-group adalah kelompok agama Kristen.

\section{Analisis data}

Teknik analisis data yang digunakan dalam penelitian ini adalah regresi linear sederhana dengan bootstrapping dan analisis moderasi. Analisis data dalam penelitian ini menggunakan pendekatan simple slope analysis dengan bantuan software Jamovi 1.0 (The Jamovi Project, 2019).

\section{H A S I L PENELIT I AN}

Subjek dalam penelitian berjumlah 203 orang $(\mathrm{N}=203)$ terbagi dalam kelompok kontrol 48,3\% (N=98) dan kelompok eksperimen 51,7\% ( $=105)$. Sebanyak 47,8\% ( $=97)$ subjek berjenis kelamin laki-laki dan $52,2 \%(\mathrm{~N}=106)$ berjenis kelamin perempuan. Rentang usia subjek berkisar 18-22 tahun dengan rerata usia 20,06 tahun dan SD 0,85. Berdasarkan program studi yang diikuti, 36,9\% (N=75) subjek merupakan mahasiswa program studi Soshum, 30\% (N=61) mahasiswa program studi Ilmu Alam, sebanyak 23,2\% (N=47) lainnya berasal dari program studi Teknik, dan sisanya 9,9\% ( $N=20)$ merupakan mahasiswa program studi Kesehatan.

Berdasarkan preferensi politik, subjek terdiri atas 42,2\% (N=87) nasionalis, 51,7\% (N=105) nasionalis religius, dan 5,4\% (N=11) memiliki preferensi politik negara berdasarkan hukum agama. Organisasi mahasiswa ekstra kampus yang diikuti subjek terdiri atas 28,1\% (N=57) Himpunan Mahasiswa Islam, 28,6\% (N=58) Kesatuan Aksi Mahasiswa Muslim Indonesia, 26,6\% (N=54) Pergerakan Mahasiswa Islam Indonesia, 10,3\% ( $\mathrm{N}=21)$ Keluarga Mahasiswa Nahdlatul Ulama, 3,9\% (N=8) Ikatan Mahasiswa Muhammadiyah, dan 2,5\% (N=5) berasal dari Lembaga Dakwah Kampus. Status keikutsertaan subjek yaitu $24,6 \%(\mathrm{~N}=50)$ sebagai pengurus harian, 67\% $(\mathrm{N}=136)$ sebagai anggota, dan $8,4 \%(\mathrm{~N}=17)$ merupakan simpatisan.

Sebanyak 5,4\% (N=11) subjek dalam penelitian memiliki pengeluaran bulanan di bawah satu juta rupiah, 90,6\% (N=184) lainnya berkisar antara satu hingga tiga juta rupiah, dan sisanya 3,9\% $(\mathrm{N}=8)$ berkisar antara tiga hingga enam juta rupiah.

Tabel 1. Analisis Deskriptif Variabel

\begin{tabular}{|c|c|c|c|c|c|}
\hline Variabel & $\mathbf{n}$ & $\begin{array}{c}\text { Mean } \\
\text { Minimum }\end{array}$ & $\begin{array}{c}\text { Mean } \\
\text { Maksimum }\end{array}$ & Rerata Mean & SD \\
\hline Fundamentalisme Agama & 203 & 2,05 & 3,80 & 2,87 & 0,41 \\
\hline Narsisme Kolektif & 203 & 1,78 & 4 & 4,71 & 0,46 \\
\hline Out-group Derogation & 203 & 4 & 8 & 6,1 & 1,12 \\
\hline
\end{tabular}


Data dalam penelitian ini bersifat normal dan homogen. Hasil uji asumsi normalitas (skewness dan kurtosis) dan homogenitas (Levene's test dan Welch's test) variabel dalam penelitian ini dapat dilihat pada Tabel 2 .

Tabel 2. Uji Asumsi Normalitas dan Homogenitas

\begin{tabular}{|c|c|c|c|c|c|}
\hline Variabel & $\mathbf{n}$ & Skewness & Kurtosis & Levene's test & Welch's test \\
\hline \multirow{2}{*}{ Fundamentalisme Agama } & 98 & 0,081 & $-0,504$ & \multirow{2}{*}{$0,862^{*}$} & \\
\hline & 105 & $-0,052$ & $-0,519$ & & \\
\hline \multirow{2}{*}{ Narsisme Kolektif } & 98 & 0,575 & $-0,116$ & \multirow{2}{*}{$0,288^{*}$} & \\
\hline & 105 & 0,386 & 0,377 & & \\
\hline \multirow{2}{*}{ Out-group Derogation } & 98 & $-0,104$ & $-0,965$ & \multirow{2}{*}{$0,010^{*}$} & \multirow{2}{*}{$0,997^{*}$} \\
\hline & 105 & 0,101 & $-0,601$ & & \\
\hline
\end{tabular}

$* \mathrm{p}<0.05$

Hasil pengujian hipotesis menggunakan simple slope analysis dijelaskan sebagai berikut.

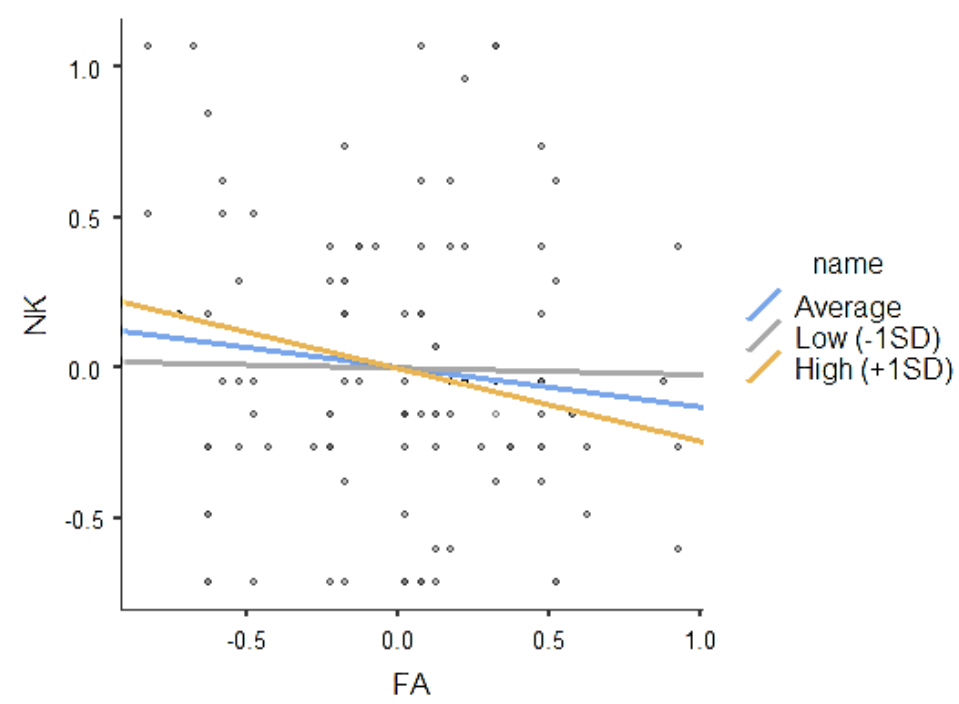

Gambar 1. Simple slope plot $\mathrm{X}, \mathrm{Z}, \mathrm{Y}_{1}$

Tabel 3. Uji Regresi X, Z, $Y_{1}$

\begin{tabular}{lcccccc}
\hline \multirow{2}{*}{ Variabel } & \multirow{2}{*}{ B } & \multirow{2}{*}{ SE } & \multicolumn{2}{c}{$\begin{array}{c}\text { 95\% Confidence } \\
\text { Interval }\end{array}$} & \multirow{Z}{*}{$\boldsymbol{Z}$} & \multirow{2}{*}{$\mathbf{P}$} \\
\cline { 4 - 6 } & & & Lower & Upper & & \\
\hline $\begin{array}{l}\text { Fundamentalisme } \\
\text { Agama (FA) }\end{array}$ & $-0,132$ & 0.0784 & -0.2789 & 0.0275 & -1.68 & 0.092 \\
\hline Priming & 0.0780 & 0.0661 & -0.0641 & 0.2012 & 1.18 & 0.238 \\
\hline FA* priming & -0.2187 & 0.1672 & -0.5547 & 0.1309 & -1.31 & 0.191 \\
\hline
\end{tabular}


Tabel 4. Estimasi Simple Slope $\mathrm{X}, \mathrm{Z}, \mathrm{Y}_{1}$

\begin{tabular}{|c|c|c|c|c|c|c|}
\hline \multirow[t]{2}{*}{ Variabel } & \multirow[t]{2}{*}{ B } & \multirow[t]{2}{*}{ SE } & \multicolumn{2}{|c|}{$\begin{array}{l}\text { 95\% Confidence } \\
\text { Interval }\end{array}$} & \multirow[t]{2}{*}{$Z$} & \multirow[t]{2}{*}{$\mathbf{P}$} \\
\hline & & & Lower & Upper & & \\
\hline Average & -0.1320 & 0.0786 & -0.278 & 0.0327 & -1.679 & 0.093 \\
\hline Low (-1 SD) & -0.0227 & 0.1218 & -0.271 & 0.2151 & -0.187 & 0.852 \\
\hline $\operatorname{High}(+1 \mathrm{SD})$ & -0.2413 & 0.1069 & -0.439 & -0.0159 & -2.257 & 0.024 \\
\hline
\end{tabular}

Peneliti gagal menolak $\mathrm{Ho}_{1}$ bahwa fundamentalisme agama $(B=-0,132, S E=0,076, p=0,092)$ tidak berpengaruh signifikan terhadap narsisme kolektif. Peneliti juga menolak $\mathrm{H}_{3}$ bahwa interaksi antara fundamentalisme agama dan priming $(B=-0,218, S E=0,167, p=0,191)$ berpengaruh positif pada narsisme kolektif.

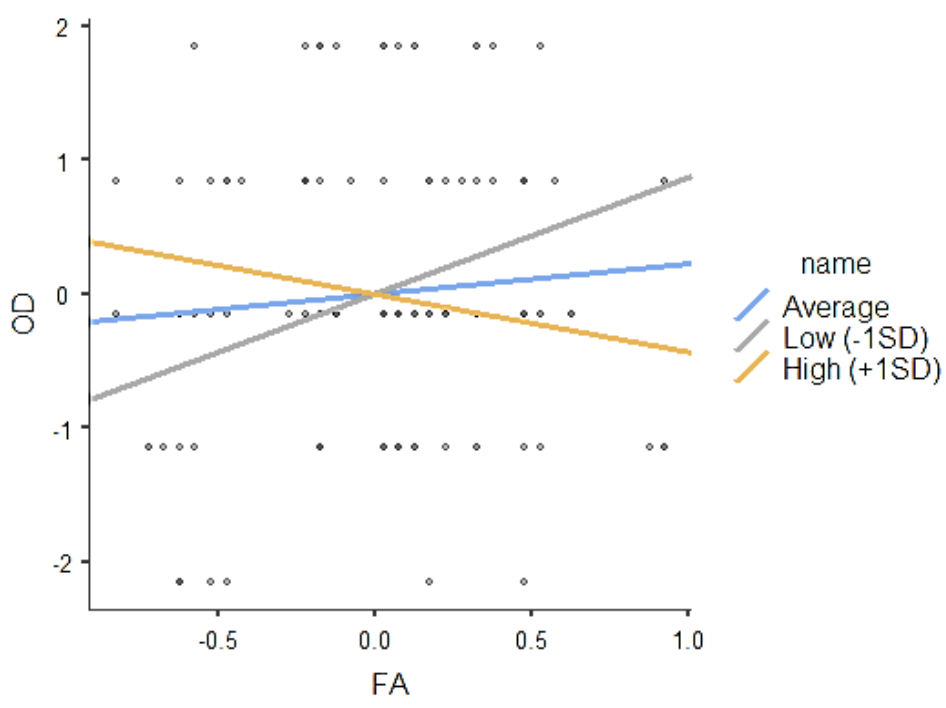

Gambar 2. Simple slope plot $\mathrm{X}, \mathrm{Z}, \mathrm{Y}_{2}$

Tabel 5. Uji Regresi X, Z, $Y_{2}$

\begin{tabular}{|c|c|c|c|c|c|c|}
\hline \multirow[t]{2}{*}{ Variabel } & \multirow[t]{2}{*}{ B } & \multirow[t]{2}{*}{ SE } & \multicolumn{2}{|c|}{$\begin{array}{l}\text { 95\% Confidence } \\
\text { Interval }\end{array}$} & \multirow[t]{2}{*}{$Z$} & \multirow[t]{2}{*}{$\mathbf{P}$} \\
\hline & & & Lower & Upper & & \\
\hline $\begin{array}{l}\text { Fundamentalisme } \\
\text { Agama (FA) }\end{array}$ & 0.2219 & 0.181 & -0.156 & 0.576 & 1.2233 & 0.221 \\
\hline Priming & -0.0147 & 0.159 & -0.300 & 0.300 & -0.0925 & 0.926 \\
\hline FA * priming & -1.2969 & 0.386 & -2.053 & -0.545 & -3.3623 & $<.001$ \\
\hline
\end{tabular}


Tabel 6. Estimasi Simple Slope X, Z, $\mathrm{Y}_{2}$

\begin{tabular}{|c|c|c|c|c|c|c|}
\hline \multirow{2}{*}{ Variabel } & \multirow[t]{2}{*}{ B } & \multirow[t]{2}{*}{ SE } & \multicolumn{2}{|c|}{$\begin{array}{l}\text { 95\% Confidence } \\
\text { Interval }\end{array}$} & \multirow[t]{2}{*}{$Z$} & \multirow[t]{2}{*}{$\mathbf{P}$} \\
\hline & & & Lower & Upper & & \\
\hline Average & 0.222 & 0.185 & -0.178 & 0.5851 & 1.20 & 0.230 \\
\hline $\operatorname{Low}(-1 \mathrm{SD})$ & 0.870 & 0.304 & 0.256 & 1.4233 & 2.87 & 0.004 \\
\hline $\operatorname{High}(+1 \mathrm{SD})$ & -0.426 & 0.224 & -0.886 & 0.0140 & -1.90 & 0.057 \\
\hline
\end{tabular}

Peneliti gagal menolak $\mathrm{Ho}_{2}$ bahwa fundamentalisme agama $(B=0,221, S E=0,181, p=0,221)$ tidak berpengaruh signifikan terhadap out-group derogation. Peneliti juga menolak $\mathrm{H}_{4}$ bahwa interaksi antara fundamentalisme agama dan priming $(B=-1,296, \mathrm{SE}=0,386, p<0,001)$ berpengaruh positif pada outgroup derogation.

\section{IS K US I}

Data dalam penelitian ini memenuhi asumsi normalitas dan homogenitas sehingga dapat dianalisis menggunakan metode regresi linear dengan moderasi. Distribusi data yang normal menunjukkan bahwa hasil penelitian pada variabel-variabel ini dapat digeneralisasikan pada keseluruhan sampel.

Pengujian hipotesis menunjukkan bahwa hipotesis null $1\left(\mathrm{Ho}_{1}\right)$ gagal ditolak, yaitu fundamentalisme agama tidak berpengaruh signifikan terhadap narsisme kolektif. Besaran pengaruh yang tidak signifikan dapat disebabkan karena pemilihan konsep fundamentalisme agama sebagai faktor yang memengaruhi narsisme kolektif baru didasarkan pada asumsi teoritis. Asumsi tesebut menyatakan narsisme kolektif dapat dimiliki individu terkait identitas sosial apa pun termasuk kelompok agama (de Zavala, dkk, 2009). Hasil yang tidak signifikan juga disebabkan konsep fundamentalisme agama yang diukur dalam penelitian ini hanya memuat kepercayaan individu terhadap seperangkat ajaran agama(Altemeyer \& Hunsberger, 1992), sedangkan salah satu karakteristik narsisme kolektif adalah individu memperlukan validasi eksternal bahwa in-group memiliki citra yang positif (de Zavala, dkk, 2009).

Hasil yang sama juga ditemukan dalam pengujian hipotesis yang menunjukkan hipotesis null $2\left(\mathrm{Ho}_{2}\right)$ gagal ditolak, yakni fundamentalisme agama tidak berpengaruh signifikan terhadap out-group derogation. Hasil ini sesuai dengan pendapat Allport (1954) bahwa pada berbagai konteks, tingkatan out-group derogation cenderung rendah karena social desirability yang tinggi. Selain itu, termometer perasaan sebagai alat ukur out-group derogation dalam penelitian ini belum memberikan ilustrasi iklim persaingan yang meningkatkan tendensi untuk menampilkan sikap negatif terhadap out-group (Lehr dkk, 2017).

Efek moderasi priming tidak ditemukan $\left(\mathrm{H}_{3}\right.$ ditolak) atau memiliki arah hubungan yang tidak sesuai $\left(\mathrm{H}_{4}\right.$ ditolak) dalam pengaruh fundamentalisme agama terhadap narsisme kolektif dan out-group derogation memiliki beberapa penjelasan. Schimmack dkk (2017) mengungkapkan bahwa penggunaan metode priming pada berbagai penelitian yang mereplikasi teknik priming banyak menuai kegagalan dan menunjukkan hasil yang tidak signifikan. Isu replikasi priming ini diulas oleh Schimmack dkk (2017) terkait bab 4 dalam buku Daniel Kahneman yang berjudul "Thinking Fast and Slow". Bab tersebut memuat priming sebagai temuan penting dalam Psikologi Sosial. Schimmack dkk (2017) kemudian menuliskan beberapa polemik terkait temuan-temuan priming yang dimuat dalam bab tersebut antara lain, signifikansi efek priming yang rata-rata rendah dan hanya diujikan pada sampel yang kecil; serta kegagalan besar-besaran dalam replikasi priming dengan tingkat keberhasilan replikasi dalam studi Psikologi Sosial hanya 25\%. 


\section{S I M P U L A N}

Secara umum, fundamentalisme agama tidak memiliki pengaruh signifiikan terhadap narsisme kolektif dan out-group derogation pada aktivis mahasiswa perguruan tinggi negeri. Hal ini berlawanan dengan temuan-temuan fenomena di media massa terkait penyebaran paham-paham fundamentalisme di lingkungan kampus yang dianggap menjadi sumber permasalahan prasangka. Fundamentalisme agama hanya merupakan bentuk kepercayaan terhadap ajaran agama dan diperlukan penelusuran lebih lanjut terkait faktor-faktor yang memengaruhi bias antarkelompok agama.

Efek moderasi priming representasi kognitif atas agama memiliki hasil yang negatif terhadap narsisme kolektif dan out-group derogation. Hal ini menunjukkan bahwa pemaparan terhadap konsep-konsep agama tanpa disertai ilustrasi persaingan atau konflik tidak menimbulkan prasangka.

Penelitian ini memiliki kekurangan terkait treatment eksperimen yang tidak memberikan gambaran persaingangan atau konflik yang nyata tentang in-group dan out-group. Penelitian selanjutnya disarankan menambahkan hal tersebut. Terkait pengukuran out-group derogation, penelitian selanjutnya diharapkan menambahkan skala social desirability agar mendapatkan data yang lebih valid.

Hasil penelitian ini menunjukkan bahwa afiliasi mahasiswa dengan organisasi ekstra kampus tidak meningkatkan kecenderungan perilaku negatif terhadap kelompok out-group. Pemberian perlakuan priming representasi kognitif atas agama justru menurunkan tingkat out-group derogation. Hal dapat dijadikan dasar pertimbangan bahwa paparan konsep-konsep agama kepada mahasiswa dalam tatanan tertentu mungkin menurunkan kecenderungan sikap negatif terhadap kelompok out-group.

\section{UCAPAN TERIMAKASIH}

Penulis berterima kasih kepada responden dan semua pihak yang terlibat dalam penelitian ini sehingga penelitian dapat terselesaikan dengan baik.

\section{DEKLARASI POTENSI TERJADINYAKONFLIK KEPENTINGAN}

Diah Budiarti dan Rakhman Ardi tidak bekerja, menjadi konsultan, memiliki saham, atau menerima dana dari perusahaan atau organisasi mana pun yang akan mengambil untung dari naskah ini, dan telah mengungkapkan bahwa ia tidak memiliki afiliasi selain yang telah disebut di atas.

\section{PUSTAKA ACUAN}

Allport, G. W. (1954). The nature of prejudice. The Nature of Prejudice. https://doi.org/10.1037/07085591.35.1.11

Altemeyer, B., \& Hunsberger, B. E. (1992). Altemeyer Hunsberger (1992) Authoritariansim, religious fundamentalism, quest, and prejudice. International Journal for the Psychology of Religion. https://doi.org/10.1207/s15327582ijpr0202_5

de Zavala, A. G., Cichocka, A., \& Bilewicz, M. (2013). The Paradox of In-Group Love: Differentiating Collective Narcissism Advances Understanding of the Relationship Between In-Group and OutGroup Attitudes. Journal of Personality, 81(1), 16-28. https://doi.org/10.1111/j.14676494.2012.00779.x 
de Zavala, A. G., Cichocka, A., Eidelson, R., \& Jayawickreme, N. (2009). Collective Narcissism and Its Social Consequences. Journal of Personality and Social Psychology. https://doi.org/10.1037/a0016904

Dhani, A. (2016). Persoalan Intoleransi Bukan Hanya di Jakarta. Retrieved November 1, 2016, from https://tirto.id/persoalan-intoleransi-bukan-hanya-di-jakarta-bZHE

Duck, R. J., \& Hunsberger, B. (1999). Religious orientation and prejudice: The role of religious proscription, right-wing. International Journal of Phytoremediation. https://doi.org/10.1207/s15327582ijpr0903_1

Freud, S., \& Dickson, A. (1985). Civilization, society and religion : group psychology, civilization and its discontents and other works. Pelican Freud library; v.12.

Heriyanto. (2018). Bogor, Radikalisme Mahasiswa, dan Ketegasan Pemimpin (1). Retrieved June 24, 2018, from https://www.beritasatu.com/satu/498011/bogor-radikalisme-mahasiswa-danketegasan-pemimpin-1

Johnson, M. K., Rowatt, W. C., \& Labouff, J. P. (2012). Religiosity and prejudice revisited: In-group favoritism, out-group derogation, or both? Psychology of Religion and Spirituality. https://doi.org/10.1037/a0025107

Lehr, S. A., Ferreira, M. L., \& Banaji, M. R. (2017). When outgroup negativity trumps ingroup positivity: Fans of the Boston Red Sox and New York Yankees place greater value on rival losses than ownteam gains. Group Processes \& Intergroup Relations, 136843021771283. https://doi.org/10.1177/1368430217712834

Nadhlir, M. (2018). Tahun 2017, Pelanggaran Kebebasan Beragama Terbanyak di Jawa Barat. Retrieved January 15, 2018, from https://nasional.kompas.com/read/2018/01/15/18233341/tahun-2017pelanggaran-kebebasan-beragama-terbanyak-di-jawa-barat

Rowatt, W. C., Tsang, J. A., Kelly, J., LaMartina, B., McCullers, M., \& McKinley, A. (2006). Associations between religious personality dimensions and implicit homosexual prejudice. Journal for the Scientific Study of Religion. https://doi.org/10.1111/j.1468-5906.2006.00314.x

Sahlan, M. (2017). Radikalisme Agama di Indonesia. Retrieved from http://www.nu.or.id/post/read/78246/radikalisme-agama-di-indonesia

Schiefer, D., Möllering, A., Daniel, E., Benish-Weisman, M., \& Boehnke, K. (2010). Cultural values and outgroup negativity: A cross-cultural analysis of early and late adolescents. European Journal of Social Psychology. https://doi.org/10.1002/ejsp.745

Schimmack, Ulrich; Heene, Moritz; Kesavan, K. (2017). Reconstruction of a Train Wreck: How Priming Research Went off the Rails. Retrieved February 2, 2017, from https://replicationindex.com/2017/02/02/reconstruction-of-a-train-wreck-how-primingresearch-went-of-the-rails/

Tajfel, H. (2010). Social identity and intergroup relations (Vol. 7). Cambridge University Press.

The Jamovi Project. (2019). jamovi (Version 1.0) [Computer Software]. Retrieved from https://www.jamovi.org. 